\title{
Assessing the Role of Artisanal and Small-Scale Mining in Poverty Alleviation: A Case of Barn Mining Area, Ward 25 Matopo: Matabeleland South Province
}

\author{
Sibanda Sindiso Marther \\ Department of Geography, Faculty of Science \\ Bindura University of Science Education, Bindura, Zimbabwe \\ Mapuva Jephias \\ Department of Geography, Faculty of Science \\ Bindura University of Science Education, Bindura, Zimbabwe \\ E-mail: mapuva@gmail.com \\ Tambura Prudence \\ Department of Geography, Faculty of Science \\ Bindura University of Science Education, Bindura, Zimbabwe
}

Received: December 22, 2019

Accepted: May 5, 2020 Published: May 8, 2020

doi:10.5296/emsd.v9i2.16990

URL: https://doi.org/10.5296/emsd.v9i2.16990

\begin{abstract}
This paper sought to assess the role of artisanal and small-scale mining in poverty alleviation, focusing on Barn mining area ward 25 Matopo (Matabeleland South Province). The study adopted a mixed method approach in data collection, comprising the use of questionnaires, interview guides, observation tools and focus group discussions. The study found that ASM contributes to income generation and employment creation and has become a major source of livelihood in many mineral resource endowed areas of Zimbabwe. It was concluded that ASM as an economic activity has improved livelihoods as the income affords the miners an improved standard of life in addition to the ability to buy agricultural inputs and sending their children to school. However, several challenges associated with ASM were identified. These
\end{abstract}


include lack of financial and institutional assistance, gold wars and other unfound agreements made between miners and claim owners. Loss of life in mine accidents, spread of sexually transmitted diseases are some of the negative impacts identified. The study recommended that for the benefits of ASM to be realised in terms of poverty alleviation, ASM activities should be decriminalized and financial support availed to miners.

Keywords: Poverty, Poverty alleviation, Livelihood, Artisanal and Small-scale mining

\section{Introduction}

Worldwide there has been an exponential growth in the number of people involved in artisanal and small scale mining. Estimates indicate that 10 to 15 million workers are engaged in the sector globally and over 100 million people are indirectly dependent on it (World Bank, 2009). Scholarly research agrees that there are about 9 million ASM operators in Africa and about 54 million people whose livelihoods depend on the sector (Ledwaba \& Nhlengetwa, 2016; Persaud et al., 2017). A significant proportion of people in Southern Africa are pushed into small-scale mining by their circumstances; poverty and unemployment (Van Straaten, 2000; Hilson, 2007). However, in the event of small-scale mining entrepreneurs, literature postulates that small-scale mining entrepreneurs are constituted of retrenched, unemployed and seasonal employees and some former mine workers (Hentschel et al., 2002). A report by the World Bank 2008 noted that all over the world, small-scale mining employs a considerable number of indigenous people in rural communities. As a result the sector plays a very critical role in addressing unemployment and poverty in rural areas. In Zimbabwe, unemployment is one of the biggest problems facing the government coupled with changing climate characterised by unpredictable rainfall patterns that negatively affect agricultural output. As economic instability has left limited employment opportunities in the formal sector, ASM has increasingly become an important alternative source of income especially in resource rich areas. Agricultural production has decreased partly due to climate change effects as characterised by unpredictable rainfall patterns amongst other things. The poor rainfall patterns have created a disjuncture between subsistence farmers and their expectations. One of the features of Zimbabwe's economy is the growth in ASM. The dependence on gold panning as an activity in Zimbabwe has seen a significant increase in recent years. World Bank (2013) highlighted that $84 \%$ of the population in the rural areas of Zimbabwe is below the national poverty line with underemployment and low agricultural productivity being the main contributors. With also the emergence of the land reform program by the government, communities have emerged haphazardly into virgin land where abandoned mines existed. This has led to the scrambling for the gold deposits thus intensifying gold panning (Shoko and Veiga, 2004).

\section{Unpacking the Concept and Practice of Artisanal and Small Scale Mining in Zimbabwe}

ASM is an informal sector employment strategy that has taken root in recent years in Zimbabwe this was on the backdrop of high poverty and unemployment levels triggered by years of economic meltdown. It has been used as a poverty alleviation strategy and an enhancement of livelihoods. Buxton (2013) defines ASM as those activities that exploit 
mineral deposits (with the combination of geologic, physical and chemical characteristics) that allows for simplified forms of exploration, extraction, processing, and transportation. It is a form of mining in which the exploration and exploitation phases can occur simultaneously and in which all phases of the mining cycle can involve low capital intensive and high labour-intensive technology. ASM can involve men and women working on an individual basis as well as those working in family groups, in partnership, or as members of cooperatives or other types of legal associations and enterprises (OECD, 2016). It is common for work groups of three to twelve individuals, sometimes in family units, to share tasks at one single point of mineral extraction. At the organisational level, groups of 30 to 300 miners are common, extracting jointly one mineral deposit for example working in different tunnels, and sometimes sharing processing facilities. ASM activities are quite diverse, sometimes illegal or informal and often barely tolerated by regulatory authorities especially when they are illegal. Other ASM activities can be seasonal or year-round, long-term or following a boom-and-bust cycle (Buxton, 2013). The exploitation of natural resources, including minerals, plays an important role in connecting remote resource frontiers to the global centre (Hayter et al., 2003). Economic and agrarian transitions are occurring throughout the world in response to the impacts of climate change and economic policies. Akram-Lodhi and Kay (2009) suggest that these changes can be studied at the individual, community and regional levels. In Zimbabwe, artisanal small scale gold mining has intensified due to increasing poverty levels, unemployment and perennial drought occurrences. ASM has been adopted as part of a coping strategy to minimize the negative effects of economic hardships and drought (Hayes and Perks, 2012). Artisanal mining is potentially more lucrative than agriculture, gaining momentum in the past two decades in Zimbabwe (Mabhena, 2012).

There are several challenges emanating from ASM. The livelihood conditions of rural populations have gradually deteriorated due to the instability of their income from farming outputs. To try and deal with this socio-environmental change and meet the households' expectations, most local farmers, including the multitudes of unemployed youth in Barn are experiencing an exodus into artisanal gold mining activities. Although poverty persists in the area, artisanal gold mining has been adopted in the area as a source of income generation. This research focused on Barn area, linking ASM activities to poverty alleviation in the area.

Barn Ward 25, is an area in Matabeleland South of Zimbabwe. The area was formerly an A2 farming zone predominantly occupied by white commercial farmers. However with the resettlement scheme that took place in Zimbabwe, the area was opened up for resettlement of black communities. The area lies along the great dyke belt with concentrations of gold. Bani area has experienced an increase in ASM activities in the backdrop of high poverty levels. Scoones (2015) highlighted that in the drier parts of Masvingo and Matabeleland South, ASM is widespread and essential for livelihoods. In this study ASM and gold panning are going to be used interchangeable as they mean the same activity. The role of small-scale mining as the backbone of some local economies is seen to facilitate the development of complementary, sustainable, revenue generating activities, which may serve as a source of finance for local investors to run their small businesses (Hentschel et al., 2015).

According to Chupenzi et al., (2009), evidence suggests that ASM is being used to produce 
income to provide for basic needs such as food, children's education, health care, clothing, and shelter, most being important components of the Millennium Development Goals (MDGs). However, the benefits may not be spread equitably among men and women in a community and are context-dependent. This is because gold-bearing rock in some mining sites may become increasingly difficult to access (EARF, 2018). This has led to some studies in other African settings having shown that ASM may actually lead to a decline in income (World Bank, 2008). The decline in income being mainly attributed to the low amount of gold that is recovered during the extraction processes.

\section{Description of Study Area}

The study area of Barn area, ward 25 in Matopo District is principally a rural province renowned mainly for cattle rearing owing to its semi-arid climate. The area is also agro-based having farming produce as the main source of livelihood for the resettled communities. Barn area Ward 25 has Mangwe bordering it to the west, Umzingwane and Gwanda districts to the east and to the north Bulawayo City and Umguza District. Shashe River forms the southern boundary and serves as a natural border between Zimbabwe and Botswana. Apart from Shashe River the district also has four other perennial rivers, namely Shashane, Hovi, Mwewe and Mhabhinyana rivers. Matopo District is made up of 25 wards divided into Northern and Southern regions. The wards are a mixture of communal areas taking up to $49 \%$ of the total area in the district and the rest are resettlements. Some people however have made a shift to artisanal and small-scale gold mining in the area. Rainfall patterns in this area are very erratic since the area lies in a semi-arid area classified under agro-ecological Region IV. Droughts and a lack of economic opportunities have resulted in widespread poverty in Matopo.

\section{Methodology}

The study adopted a mixed method approach which is a hybrid of both qualitative and quantitative research methods. Mixed method can be described as a type of research design in which a researcher or team of researchers combines elements of qualitative and quantitative research approaches for the purposes of breadth and depth of understanding and collaboration (Johnson et al., 2007). This method was chosen because of its methodological benefits such as the balance in objectivity and scientific rigour. Qualitative research focuses on the collection and analysis of full, rich and contextual data about a phenomenon (Limb and Dwyer, 2001). Quantitative research design focuses on the analysis and presentation of precise, theory informed numerical information (Johnson et al., 2007). When qualitative and quantitative research strategies are combined in a single research, the advantages of each methodology complements the other, making a stronger research design which results to more valid and reliable findings (Bowen, 2002). The main quantitative technique that was applied in this study was the questionnaire survey while the main qualitative techniques applied were focus group discussions, interviews and observations. Qualitative data on the other hand supported the exploratory nature of this research because the study sought to discover new insights and ideas on the impact of gold panning on poverty alleviation. The qualitative data gave a contextual interpretation of the data collected when it was analysed 
and presented in the form of graphs and pie charts.

The target population for this study included small-scale miners from the Barn mining area, Ward 25 inhabitants, Matopo Rural District Council officials, Environmental Management Agency officials, Ministry of Mines and Mineral Development and other key informants which the researchers incorporated during the study. Convenience sampling was used to select artisanal miners and community members to interview based on their proximity to where ASM activities occur. Dornyei (2007) defined convenience sampling as a method where a sample of a target population is selected based on certain criteria such as expenses on the researcher, geographical proximity, accessibility and availability at a certain time. This method was utilized for the research due to the nomadic nature of artisanal miners and their unwillingness to participate in the study. Also the method was chosen because the researcher knew at hand her objectives and only interviewed those people who would help her achieve the set goals. The miners are the ones on the ground and earning an income through ASM hence they were likely to give reliable information on the role of ASM in poverty alleviation. The emphasis of this study was to get an in-depth insight on the role of ASM in poverty alleviation.

The population size of the panners in the study area was approximately one-hundred and fifty at the time of the study. A representative sample of fifty gold panners, a third of the population was selected for the sample as the results were more likely to be accurate as the sample had more representatives. Snowball sampling was used in identifying the panners where by an identified respondent lead to the next one. This is because ASM activities are predominantly illegal. Therefore this technique was preferred as it allowed access to informants who are otherwise difficult to access without guidance. From the fifty miners, ten were engaged into a focus group discussion session while forty responded to questionnaires.

The researchers also incorporated five community leaders such as the district administrator, chiefs, headmen, community health officer, community development head and headmasters in close proximity to the mine. Purposive sampling was used in selecting these officials on the basis of their relevance, appropriateness and importance to the study. These were included as the target groups because they are part of development committees in their areas. The study also targeted the local people in large number because they are the ones who are directly or indirectly affected by the impacts of the mining activities. Thus, the participation of local people in a huge number provided various perceptions and views over ASM in their area. Also the involvement of three EMA staff members was important to the study because they oversee the operations of any mining activity in the district. The data captured from the questionnaires was analysed using Statistical Package for the Social Sciences version 25 (SPSS version 25). This helped to produce graphs, tables and pie-charts for presentation. Qualitative data in the form of field notes through observation and interviews was coded and analysed using thematic analysis. The final output was presented in the form of texts and direct quotes from key informants, community leaders and local community members.

The research observed privacy, secrecy and confidentiality of the information given by participants. The consent process ensured that all participants voluntarily took part in this 
study with the full knowledge of risks and benefits as they were explained to them. Ethical principles are complied with as they serve to safeguard the dignity, right, safety and wellbeing of all the participants in the research (Babbie and Mouton, 2002; cited in; Luci, 2012). Ethical considerations are general guidelines that commits the researcher to protect the rights of the participant. Suttler (2006) pointed out that, research ethics refer to ethical considerations which are guidelines that demand an adherence by the researcher in order to protect the rights of the participant. The researcher made it clear to the participants that participation in the study was purely on a voluntary basis. No threats or some form of incentives were used to coerce participants. Prior to interviews informed consent was sought from individual participants.

\section{Results and Discussion}

The main method of mining in Barn mining area is open shaft mining. The majority of the small- scale miners do not have valid mining licenses, but operate illegally. Most of the employed miners work for mine claim owners. The findings through researcher observation indicated that the miners use simple tools such as head pans, shovels, pick and axes. Some who have licences use modern equipment such as excavators to clear the land these are usually sponsored miners.

The demographic profile of the gold panners included age, gender, educational profile and area of origin of the respondents. The age aspect showed that most of the gold panners are between the ages 18 to 50 with most of them having basic education. Most of the panners are between the ages 25-34, and Kori (2006) attributed the prevalence of a young age and the male sex to the physical demands of gold panning activities. Most of the people in this age group are failing to be absorbed into the formal sector in terms of employment in industries as Zimbabwe is already facing economic hardships. On gender, men are the ones who are directly involved in the panning activities with a few special cases of women. Women were seen to be more involved in buying and selling of the mineral, clothes and food. The absence of men who are of the age fifty+ and a few cases of women actively involved in the mining activities maybe because of the migratory and nomadic nature of ASM including the harsh working conditions which require physically able bodied populace. The majority of the female respondents during the focus group discussions stated that they had many dependants to take care of and that they are married so they needed to take care of their homes. Dreschler (2001) asserted that the ASM sector is well known for its male dominance nature because of the physical nature of the activity and the fact that women's access to social, financial, knowledge and time is dominated by men.

The study results showed that the local community have a few economic benefits hence there is little to no economic development in the area because of mining. This is because the miners do not pay tax to the area chief and most of the claim owners are not indigenous to Matopo. As a result whatever profit that they get is invested in areas where they come from. Some of the gold panners in Matopo come from as far as Kwekwe, Chegutu, Shurugwi, Filabusi, Nkayi and Maphisa just to mention a few places. Also there are some unfound laws in sharing of the profits. The agreement of sharing profits state that from the ore extracted, 
fifty percent is for the claim owner, thirty percent is for the sponsor whilst the remaining twenty percent is for the panners to share. If miners are lucky they mostly profit from what they call "njumba", which is the molten ore that they steal during processing.

According to the responses of the gold panners and the households during focus group discussions, ASM is providing the locals in Barn with employment and a source income that caters for most domestic needs. Their involvement in ASM is so as to support household expenditures by buying soaps and clothes for children, paying their school fees and buying agricultural inputs. Those involved in both ASM and agriculture are now affording to invest their panning proceeds into farming by buying seeds, fertilisers and herbicides so as to improve their agricultural output.

ASM poses a significant capacity of accumulating wealth on households as they are managing to cater for their own needs without struggling, they are now able to earn decent living, sustaining their livelihoods from mining or buying and selling gold. Though it depends on the hardworking as well as luck of the gold panners, one of the respondents during the focus group discussions said that, they can get from (200 Bond dollars) per week on a good week and can feed themselves and their families. ASM has become a major source of income however it lacks the permanent security in accumulating wealth. Some of the gold panners in the focus group discussion characterised it as uncertain, one can get today and feed his family but it doesn't mean that they will get it all the time. One of the respondents said

"Gold panning goes by luck one can get the gold or spend months without getting anything. ASM has had a domino effect in the local economic activities" (FGD Respondent 5, 12 September 2018).

Some of the businesses rising because of ASM in Barn include taxis, second hand clothes shops, tuck-shops, bars, and food outlets. These people are making a great deal of profits from heavy spending of the artisanal and small-scale gold miners. ASM also has the potential to create local purchasing power and increase in demand of locally produced goods and services which includes tools, food, housing and infrastructure. The results show that from the respondents, $22 \%$ believed that the tuck shops that have been opened up in the area were as a result of ASM activities. Whilst $20 \%$ alluded the taxi businesses to ASM. The pie chart shows that many other businesses have stemmed up in Barn because of the gold panning. People can now buy food and clothes without the worry of going to the closest town which in this case is Bulawayo. Small businesses are becoming sources of income and entrepreneurship.

The majority of the household gold miners argued that, though they can feed their family the sector has little to do with their self-reliance and cope with the challenges they face. The sector has little to do in building more secure and resilient livelihoods for the majority household gold miners in the village as far as it failed in enabling them to get sufficient access to assets and cope with stress and shocks. It is more of a short- term and consumption oriented activity. The main challenge being the lack of financial and legal assistance as the activity is dominated by illegal miners. Also it is getting more and more difficult to reach the ore. 
Most respondents believed that small-scale mining has contributed to development in their communities in terms of provision of water. In the mining communities, some feeder roads have been constructed to link mining sites. These roads are now being used not only as a link to mining sites but also to transport to the people, goods and services. Small-scale mining has also promoted trade in Barn. The influxes of migrants as well as local miners into the studied communities have also impacted positively on trading and other commercial activities. Traders particularly food vendors and drink sellers usually make high sales when miners are making progress. The responses from participants revealed similar results by the International Institute for Environment and Development (2013) that small-scale mining provide jobs and income for twenty to thirty million of the world's poorest people and supports the livelihoods of five times that number. Thus, artisanal and small-scale mining employs ten times more people than large-scale mining and serves as a means of rural development.

The community leadership in Barn highlighted that mining operations in ASM are useful in basic skill development and contribute to the transformation of unskilled labour into semi-skilled and skilled workers. Because of low barriers to entry in terms of capital needs and formal educational requirements, small-scale mining operations offer excellent opportunities for the development of indigenous entrepreneurs. In many rural areas where white collar jobs are non-existing and the available jobs are of low paying, the only means of survival for the majority is to take up employment in the small-scale mining sector.

However when the leadership in the Barn area was interviewed they felt that development in terms of infrastructure brought in by ASM was not enough. Some attributed this to the gold panners being from other areas. They claimed that whatever profits the gold panners made, they were taking it back to their areas of origin. Gold panners in Barn were also not paying taxes as most of them are illegal therefore it's difficult to do a follow up and have them pay tax that will help in development such as establishing schools and clinics.

Artisanal and small scale miners are faced with many health and safety risks. First and foremost the miners do not have the appropriate clothing to be working in the shafts. Air pollutions through blasting and dust fumes adversely affect the health and well-being of gold miners as well as communities residing around. Health risks with the activities of ASM which includes exposure to dust, effects of noise and vibration, effects of poor ventilation puts the lives of miners at risk.

Inadequate roof supports result in cave-ins leading to high risks of accidents in pits and underground areas. Gold miners dig holes 5- 20 meters even kilometers, and try to enlarge them in different directions hoping to increase their chances of getting gold. Wooden logs are used to balance the pulley system that lowers the miners into the pits. Community leaders in the interviews said they have heard of many cases of gold panners who perish in shafts. These results were in agreement with Akabzaa and Darimani (2001) who highlighted that most of the accidents in gold panners' mining activities are caused by unsafe mining conditions. Other gold panning related health risks include skin disease, diarrhoea from poor sanitation and Sexually Transmitted Diseases (STDs) and HIV/AIDS. Gold miners are vulnerable to high incidence of STDs and HIV/AIDS due to high prevalence of prostitution in 
the area. The availability of the young and sexually active in addition to their mobility contribute to the spread of sexually transmitted diseases. M'pele (2002) confirms that having the combination of the young and very mobile population has contributed to the increase of HIV/AIDS.

Another issue is that only the indigenous community respondent has access to shelter while the migrant gold miners live in temporary houses made of plastics. This exposes the miners to poor sanitary conditions as they do not have toilets and water sources. This in turn exposes the miners and the people to hygiene related diseases such as cholera and typhoid. In most cases, the miners build shacks using sticks and plastics and it is barely habitable for any human being, with no water sources and ablution facilities on site. ASM as a livelihood strategy has higher environmental costs than the large scale mining. The number of individual polluters from ASM has significant impacts on the environment. ASM creates negative environmental impacts on physical environment during its different stages of exploration, processing and closure (Hilson, 2000). As in most cases of other mining communities, ASGM in Barn area has environmental problems. The area is exposed to land degradation, deforestation, landscape destruction and soil erosion. Through observation the researcher observed that the miners are causing land degradation. Gold miners open mining pits which pose risks to livestock and wild life resource in the area. When surveying for gold massive areas of forest land is cleared leaving the soils bare and uncovered and a disturbing the ecosystem balance in the area. During the study $73 \%$ of the miners said they felt the land was extremely degraded especially by clearing land, digging pits and leaving the pits uncovered. One of the miners responded by saying:

"We are very mobile, we are after money and because the work we do is illegal we do not have time to be covering pits and planting trees. When we do not find anything we move on to the next are leaving pits everywhere as you can see for yourself' (Artisanal miner, focus group discussion Barn, 15 September 2018).

On shelter, most of them live where they work. They dig pits very close to each other with rocks from excavation left on the surface. Most of the trees and plants show a brownish colour from the dust particles from the mining operations. There is poor waste management with bottles and papers scattered on the ground.

Air pollution in the area is mainly in particulate matter that is emissions of black smoke, dust, noise and vibration. All fine dust at a high level of exposure has the potential to cause respiratory diseases and also increases the condition of people with asthma and arthritis. Dust from gold mining operations has a high silica content, which has been responsible for silico-tuberculosis in the mining area (Akabzaa and Darimani, 2001). The release of dust through digging and clearing of land cover are some of the causes of atmospheric impacts of small-scale that was noted during field work. From the miners' responses $60 \%$ of the miners seemed to think that the air pollution was low, while $40 \%$ said it was moderate. However from the time of arrival the researcher observed that the air pollution especially with dust particles was extreme in the blasting zones.

It was noted that small-scale miners are moving very close to roads, thereby putting people's 
lives at risk. Some respondents revealed that footpaths leading to their respective farms are being blocked by the miners during their operations, without any alternative. These findings can equally be related to the findings of the Centre for Development Studies (2004), that small-scale mining sector is strongly associated with widespread land degradation, loss of biodiversity, natural resources and deforestation. Akabzaa and Darimani (2001) also came out with similar findings when they revealed that, extensive areas of land and vegetation in Tarkwa mining area in Ghana. The main economic challenges that were raised by the miners during focus group discussion were financial problems in creating sustainable livelihoods within the ASM mining. The lack of organisational and legal support and micro-credits negatively affects ASM activities. The government and NGOs view ASM as illegal and informal hence there is no financial support which then poses a great challenge for the sector's role in enhancing the sustainable livelihoods of the rural community.

"The major challenge is that we do not have any support from the government or NGOs. The only thing that the Government does in this area is send the police and EMA officials to arrest those of us who do not have mining licences. As for now we do not have money to get licences. As for now my sister we wish we could get support from the Government and loans to support our activities" (Artisanal miner, focus group discussion, 15 September 2018)

Miners process their activities using basic tools such as shovels and picks and these are inadequate with the nature of the work that is done. Gold miners claimed that they lack the financial capacity to afford mechanised technology. Such constraints limit the extraction capacity of the miners in turn cutting down the profits that they could make if they had mechanised technology so they believe.

It was also noted that the gold miners are always vulnerable to different social problems. This is because there is no strong organizational support for ASM and no one has responsibility in the sector. During the survey, the gold miners were hiding themselves in fear of the researcher in case they were military, law enforcement or EMA officials. According to the ward leadership, the government has been using military forces in areas where ASM is being practised. The military is used to maintain peace when gold wars erupt. Thus, gold miners not only lose trust among each other but also among military forces in the area. As majority of the illegal gold panners stated, military forces and the actions they take is another main problem in their daily mining activity. One of the miners had this to say:

"My sister we do not trust new faces here, especially people we see carrying papers like you. Sometimes we have people investigating this area so that they know how much money we make, some want to make arrests so we are never sure of your intentions" (Artisanal miner 8, 15 September 2018)

It was also noted that illegality and lack of institutional support from the government also creates major problem in service provision activities by the local government. The gold panners complained during the focus group discussion that the only presence of the government in the area is to arrest them instead of supporting them. Another major issue that emerged is that most of the gold panners are into drugs such as marijuana and most of them take home brewed beer called "isikokiyana" and these get them highly intoxicated. The 
reason being small-scale mining is regarded as a hazardous activity, therefore majority of the miners take addictive and stimulant drugs to enable them work beyond their limits. From the survey $15 \%$ of the respondents admitted to using drugs.

In addition, there is a high rate of crimes and insecurity. The leadership at Barn have complained that the panners have reportedly committed crimes of rape and house breaking. Most of these crimes were blamed on miners from other districts who after committing crimes leave the area. Killings have also taken place in Barn over gold. Conflict and violence among gold miners and migrants are common in Barn mining area. The gold panners group themselves according to their places of origin.

The ward head said that when a certain group finds an area rich in gold they start to fight over the area.

"Most of the gold wars here are over areas that seem to have high gold deposits. Once other gold panners suspect that one is getting high returns from his extractions they try to take over and this results in wars. Many panners have died because of this. They simply push each other into open pits" (Community leadership Barn, 18 September 2018)

One old lady during the household focus group discussion said "Lapha ungathola indawo elegolide elinengi akumelanga utshengisele ngoba uyabulawa, ufele igolide lakhona". (Interpreted this means when one hits a jackpot of gold they are not supposed to show off in their spending habits otherwise they get killed).

The leaders of the Barn community also highlighted that they did not like the fact that most miners in the area where from other districts. The questionnaire responses showed that from the people who responded $58 \%$ were from other districts while $42 \%$ were from Barn. The districts highlighted in the questionnaire include Filabusi, Nkayi, Kwekwe, Shurugwi and Maphisa. This was a concern raised by the leadership during the interview which made them feel that the locals were not benefiting as much because of this.

"Most of the gold panners here are from other places. When they arrive here they group themselves according to their places of origin and keep on attracting others to come and join them. A few of the locals work in these mines and I believe this is why locals are not benefiting as much as they otherwise would" (Community leadership Barn, Interview, 18 September 2018)

Also the mining agreements between claim owners and the gold panners appeared to be one sided. The agreements do not have compensation packages for those who die or get injured in mining activities. Once one is injured they lose their source of income and their ability to work, trapping them in the cycle of poverty. The other agreements are that whatever sells the claim miner makes, $50 \%$ goes to the claim owner while $30 \%$ is given to the sponsor and $20 \%$ is shared among the panners. The sponsor is the one who provides the panners with money to buy food and mining equipment to use while working at the mining site. Sometimes the panners end up getting \$20 bond on a bad day to share amongst five or more people.

Cases of teenage pregnancies leading to temporary marriages were also recorded. Young 
ladies in their teen ages mostly offer themselves to the gold panners for money, due to poverty. This is as a result of the influx of miners into the mining communities and immoral acts, which results in teenage pregnancies and unplanned marriages. In so doing, they end up being impregnated by the gold panners, of whom the majorities are migrants.

"My daughter, these high school girls, when they see the gold panners they see money. They are attracted by the spending habits of these panners and think that they have money everyday. On good days the panners buy beers and do braais and these young like that and they get trapped and fall pregnant. Then they discover that the panners have wives or they have left and gone to other places" (Community member, focus group discussion Barn, 18 September 2018)

When the miners leave the communities, after the mining operations are over, the affected women are not able to locate their whereabouts and are left to their fate. Some miners who are locals leave their wives to settle down with the newly found love. This was a major social problem noted during the focus group discussions.

ASM is a major source of livelihood for many households in Barn. One of the respondents in the focus group discussions with the miners said "Ngabe akula golide lapha ngakudala sahamba eGoli ngoba izinto zinzima la, akuphileki". (Interpreted this means without gold we would have long gone to South Africa to look for better opportunities because life here is hard). Therefore the study showed that the relationship between gold panning and livelihood enhancement does exist. The income that the miners get is used to access social services such as health services and education thereby enhancing the lives of the local people at Barn. The presence of mining activities has created a demand for developments such as tarred roads, grocery shops, tuck shops, milling sites and this in turn is a form of community development.

The community developments attributed to ASM were water supply provisions, with the highest number of miners agreeing to it, followed by tarred roads and electricity. Proceeds from mining activities are also invested into agricultural inputs such as buying hoes, cattle, herbicides, seeds and fertilisers to boost agricultural output. According to Scoones (2009), agriculture is viewed as an indicator of rural livelihood enhancement Income gained from ASM changes livelihoods significantly. The results showed that the spending habits of miners enhanced their livelihoods significantly, affording them a far much better life.

Some miners have invested in physical assets such as buying cars and moving from mud houses to building brick houses in rural areas. Those who buy cars would have been lucky in their extraction. Others admitted to stealing "injumba" from their claim owners so that they can buy cars and build houses. Income varies with gold panners some make as little as \$20 bond a week and at times depending on their luck they can make as much as $\$ 200$ bond a week, meaning that averagely a month they can make up to $\$ 800$. Making the daily individual expenditure above the poverty line of $\$ 1,00$ a day. Maponga and Ngorima (2002)estimated that US\$625 is an amount an average Zimbabwean family requires for a decent life. Thus these earnings make a significant contribution to livelihood enhancement.

As evidence of socio-economic growth some artisanal miners have gone on to build houses 
within their homesteads, with some having accumulated some assets. Lucky one have even own a fleet of cars and have joined the taxi business. The gold panners who are fortunate enough have electricity supply in their homes. Above all livelihood through ASM has uncertainty hovering above it. Income is never cer;tain; sometimes miners can go for months without getting any gold at all. Also the extraction methods make the activity unsustainable. A key to livelihood improvement is ensuring that the natural resource base used by the poor is maintained and even improved. Sustainable livelihood strategies imply that the economic needs of individuals and communities are integrated into the maintenance of the environment. Poverty is multidimensional and the approaches to reduce it have to be similarly multidimensional: political, economic, social and environmental in nature so that the strategies to combat it become long lasting.

The mining laws in Zimbabwe are mostly concerned with large scale mining activities with ASM looked at from its illegality and negative environmental impacts. Only recently has ASM been recognised for its major contribution to the mineral output of the country. The literature review identified gaps in terms of the policies and laws that govern ASM. The major challenge existing being in devising pro-poor policies for artisanal and small-miners. There is need to understand the perception of the poor. By interacting with them, one can gain their trust to achieve a real and lasting ownership of the development process. The poorest miners need access to productive resources and appropriate knowledge of their use. In the case of artisanal and small-mining there is need to improve organisation and techniques. One method would be to channel some of the income to spur alternative production activities that demonstrate the possibility of sustainability. In most mineral rich rural communities, there is an over-reliance on mining as the sole potential economic engine. This dependence suggests a potential opportunity to invest mining income in other livelihood activities. Therefore there is an option for government to decriminalise ASM and offer support in up scaling of the mining technology. This may contribute towards poverty reduction in a sustainable way.

\section{Conclusion and Recommendations}

Investigation into the role of small-scale mining operations in poverty alleviation in Barn, concluded that mining activities in the area are predominantly done informally and illegally without any laid down regulations. Miners operate without any mining license and with no regard to the environment. However, the production of gold by the small-scale mining sector in the studied communities has contributed to the socio-economic lives of individuals and communities. It is believed that miners benefits more from the mining products than non-miners because they are directly involved in the mining operations in the form employment. The little that they get to sell to the informal market they get money to meet their day to day needs.

Based on the evidence from the study, it is concluded that small-scale mining gives both positives and negative effects to many individuals and households. However the socio-economic environmental, and health negative impacts of small-scale mining operations Barn outweigh the benefits derived from the mining activities. There is need for government and other stakeholders such as NGOs to have structured efforts to emancipate the locals at 
Barn so that they directly benefit from the activity. It is also imperative that the government decriminalise the activity and regulatory bodies such as EMA and law enforcement that is the police take a more pro-active stance at ASM activities. EMA could carry out periodic educational campaigns on how to carry out ASM sustainably rather than for them to be seen as reactive and an enemy to the miners' activities. The police could assist in eliminating gold wars and criminal activities instead of them being part of the fraud system by taking bribes from miners. To address these challenges and for poverty alleviation and protection of the environment, the following recommendations could be adopted to help address the socio-economic, environmental and health challenges associated with regards to small-scale mining operations in Barn:

\section{$>$ Monitoring small scale mining activities}

There is need for the Ministry of Mines and Minerals, the Environmental Management Agency, law enforcement agencies as well as community leaders to monitor small-scale mining activities to ensure that the mining activity is carried out sustainably and the benefits contribute to the development of the area. Government must ensure that mine claim owners pay tax so that the money is invested into development. Furthermore, security agencies should be well resourced and also motivated against bribery and corruption, in order to fight against illegal mining activities in the country. In addition, there is a limited capacity at the local community level to enforce laws related to small-scale mining in the studied communities. In view of this, the local community must ensure that laws relating to small-scale mining and other by-laws in the communities are strictly adhered to.

Miners must be provided with clear guidelines on how to conduct their operations and periodic educational campaigns to be carried out to ensure little or no harm to the environment. Land rehabilitation programs need to be carried out periodically where miners are engaged in covering up mining pits and this activity should be incentivised. In the studied communities, there were health related diseases that were attributed to small-scale mining activities. There is therefore, the need to educate community members on environmental and health effects, such as water pollutions from gold processing using mercury and land degradation as caused by the operations of the mines. Effective education will help reduce the adverse effects of small-scale mining on health and the environment in mining communities.

\section{$>$ Formation of small-scale mining associations}

Small-scale miners should form associations that will interact regularly with all stakeholders in the mining sector. This should involve representatives from each traditional council in the municipality. These associations will help discuss major issues regarding the small-scale mining sector, such streamlining of mining operations, procedures on loans acquisition, training on mercury use and application of technology, in order to increase productivity

\section{$>\quad$ Land rehabilitation}

ASM activities have left open pits which are 30 metres deep. There is the need to reclaim lost lands through tree planting exercises and the filling of dug-out pits in the affected communities. According to the requirements of the Forest Commission one has to plant 


\section{Macrothink Institute ${ }^{\text {th }}$}

two trees after cutting one tree. The dug- out pits are very dangerous and threaten the livelihoods of people as they result in livestock being trapped underground. Hence to reduce land degradation and loss of biodiversity, gold panners have to backfill the dug out pits. This will go a long way in protecting livestock from falling into pits and will save human lives. It will also ensure that the activity is done sustainably and that people secure a continuous income, trimming down the high rate of unemployment. Small-scale miners and mine claim owners should also be encouraged to pay taxes and fines paid under the Community Share Ownership Trust (CSOT) so that the community is developed in terms o building schools, clinics and drilling boreholes.

\section{$>$ Provision of compensations packages}

The Ministry of Mines and Minerals should put in place laws that protect people who work as gold panners for mine claim owners. Commensurable compensation packages should be given to individuals who are injured during the mining activities. There should be no delay or denial of such payments to the affected heads of households to ensure that their livelihoods are not negatively affected. Thus, compensations paid must be commensurate in order not to make the injured worse off as sometimes they are left in a state that does not allow them to carry out any economic activity.

\section{$>$ Provision of clean water sources}

Miners in the Barn mining area are mainly dependent on the water that they get from the dug pits. Once they see the water coming up they use it for cooking and drinking. This exposes the miners to a lot of water borne diseases such as cholera and typhoid. Also because of lack of proper ablution facilities, the miners sometimes relieve themselves in the same pits that they get water from. This exposes the miners to a lot of health related risks and the surrounding community expressed their concern during the focus group discussions as they also feared contracting diseases such as cholera. There is therefore need for alternative water sources to be put up in areas prevalent with the ASM activities. The government and other stakeholders including community leaders should ensure that boreholes are drilled on mining sites so that miners have access to clean water.

\section{$>$ Financial and legal support}

Financial institutions, NGOs and the government s must improve upon the capital base for miners in order to sustain their livelihoods. The government can offer financial assistance through soft loans or micro credit facilities in order to expand their operational activities. Besides, small-scale miners should be assisted with legal and organizational supports to streamline their activities. Most miners in Barn suffer because of the conditions they agree to as they seek assistance to secure equipment and tools for their mining activities. Currently in Barn whatever ore is extracted fifty percent of the sells is given to the claim owner, while thirty percent is given to the sponsor and the miners who do the hard labour are left with twenty percent to share among themselves. From that twenty percent they have to pay back the sponsor for the food they ate during their activities. At the end of the day the miners' income becomes a "hand to mouth" scenario with little to no savings at all.

\section{$>$ Awareness campaigns on HIV and substance abuse}


Gold panners get themselves involved in risky behaviour as coping strategies to the harsh conditions that the panners are exposed to and as a way of entertainment. Most of them spend their money on prostitutes, beer and marijuana commonly called "mbanje" in Barn. Gold panners' involvement with prostitutes results in high prevalence of HIV/AIDS. There is need to educate miners on the dangers of engaging in unprotected sexual activities. The Ministry of Health can spearhead such projects providing easy access to condoms. After sleeping with prostitutes who are infected some miners might go back home and infect their spouses unknowingly. Awareness campaigns should therefore not reach out to the miners only but also to the mining communities. Some miners resort to getting intoxicated on marijuana and beer. This makes some of them to be violent and engage in criminal activities. Some of the gold wars that take place are of miners who are already high. When the police and the village leaders were interviewed they highlighted that they were cases reported of gold panners involved in looting from households and breaking into homes raping women and girls. The chief alluded to the fact that such cases have been on the rise with perpetrators escaping from police custody. This raises need for awareness campaigns on the dangers of substance abuse to both the user and the community.

\section{$>$ Licensing and giving claims}

The Ministry of Mines and Minerals needs to also consider a policy where by mining claims are given only to the people who are indigenous to that particular mineral rich area. This will ensure that development takes place where mining takes place. It will also reduce criminal activities that seem to be widespread and caused by miners from other areas. There is need to fast track processes of acquisition of mineral rights, the right to renew, transfer and mortgaging mineral rights Gold panners associations also need to be set up with clear leadership structures. This will help in regulating the activities of the miners and accounting in terms of the social and environmental ills caused by ASM. There is need to regularise and formalise all gold mining activities through licensing, giving permanent claims and operating permits at lower costs. This will enable panners to recoup some of the added costs in the form of taxes.

\section{References}

Akabzaa, T., \& Darimani, A. (2001). Impact of Mining Sector Investment in Ghana: A Study of the Tarkwa Mining Region. A Draft Report Prepared for SAPRI. [Online] Available: http://www.saprin.org/Ghana

Akram-Lodhi, A. H., \& Kay, C. (2009). Neoliberal globalization, the traits of rural accumulation and rural politics: the agrarian question in the 21st century. Peasants and Globalization: Political Economy, Rural Transformation and the Agrarian Question, Routledge, London, pp. 315-38.

Bowen, G. A. (2002). Grounded Theory and Sensitizing Concepts. International Journal of Quantitative Methods, 5(3). https://doi.org/10.1177/160940690600500304

Buxton, A. (2013). Responding to the challenge of artisanal and small-scale mining. How can knowledge networks help? London (UK): IIED. [Online] Available: 
http://pubs.iied.org/pdfs/165321IIED.pdf

Chupezi, T. J., Ingram, V., \& Schure, J. (2009). Impacts of Artisanal Gold and Diamond Mining on livelihoods and the Environment in the Sangha Tri-National Park Landscape. Center for International Forestry Research (CIFOR): Yaounde, Cameroon.

Dreschler, B. (2001). Small scale mining and sustainable development within the SADC region: Mining Minerals and Sustainable Development. No. 84. England: SANTREN/ ITDG.

Dornyei, Z. (2007). Research Methods in Applied Lingistics. New York: Oxford University Press.

Hayes, K., \& Perks, R. (2012). Women in Artisanal and Small-Scale Mining Sector of the Democratic Republic of Congo. In High-Value Natural Resources and Peace Building, 529-44. London: Routledge.

Hayter, R., Barnes, T., \& Bradshaw, M. J. (2003). Relocating resource peripheries to the core of economic geography's theorizing: rationale and agenda. Area, 35, 15-23.

https://doi.org/10.1111/1475-4762.00106

Hentschel, T. (2002). Global Report on Artisanal and Small-Scale Mining. Minerals, Mining and Sustainable Development. Hilson, G. 2011a. Artisanal Mining, Smallholder Farming and Livelihood Diversification in Rural Sub-Saharan Africa: An Introduction. Journal of International Development, 23, 1031-41. https://doi.org/10.1002/jid.1829

Hentschel, T., Hruschka, F., \& Priester, M. (2012). Global Report on Artisanal \& Small-Scale Mining. [Online] Available: http://pubs.iied.org

Hilson, G., \& Pardie, S. M. (2006). An agent of poverty in Ghana's small-scale gold-mining sector?. Resource Policy, 31, 106-116. https://doi.org/10.1016/j.resourpol.2006.09.001

Hilson, G., Yakovleva, N., \& Banchirigah, S. M. (2007). To move or not to move. Reflections on the resettlement of artisanal miners in the western region of Ghana. African Affairs, 106/424, 413-436. https://doi.org/10.1093/afraf/adm038

Hilson, G. (2012). Poverty traps in small-scale mining communities: The case of sub-Saharan Africa. Can. J. Dev. Stud, 33, 180-197. https://doi.org/10.1080/02255189.2012.687352

Kori, A. (2006). 'Makorokoza': Small-scale Gold Mining in the Midlands Province of Zimbabwe. Gweru, Mambo Press.

Limb, M., \& Dwyer, F. (2001). Qualitative Methodologies for Geographers: Issues and Debate. Oxford University, Oxford

Ledwaba, P., \& Nhlengetwa, K. (2016). When policy is not enough: prospects and challenges of artisanal and small-scale mining in South Africa. Journal of Sustainable Development Law and Policy, 7(1), 25-42. https://doi.org/10.4314/jsdlp.v7i1.2

Luci, A. (2012). Research Design \& Methodology. [Online] Available:

http://linkwits.ac.za/training 


\section{Macrothink}

Environmental Management and Sustainable Development

ISSN 2164-7682

2020, Vol. 9, No. 2

Mabhena, C. (2012). Mining with a 'Vuvuzela': Reconfiguring Artisanal Mining in Rural areas of Zimbabwe and Its Implications to Rural Livelihoods. Journal of Contemporary African Studies, 30(2), 219-33. https://doi.org/10.1080/02589001.2012.664416

Maponga, O., \& Ngorima, C. F. (2003). Overcoming environmental problems in the gold panning through legislation and education: the Zimbabwean experience. Journal of Cleaner Production, 11(2), 147-157. https://doi.org/10.1016/S0959-6526(02)00034-3

M'Pele, P. (2002). Problematique du VIH/SIDA et exploitation miniere artisanale. Presentation at the Seminar on Artisanal and Small-scale Mining in Africa, Yaoundé, Cameroon.

OECD. (2016). OECD Due diligence guidance for responsible supply chains of minerals from conflict-affected and high-risk areas. 3. edition. Paris (FR): OECD.

https://doi.org/10.1787/9789264252479-en

Persaud, A. W., Telmer, K. H., Costa, M., \& Moore, M. L. (2017). Artisanal and small-scale gold mining in Senegal: livelihoods, customary authority, and formalization. Society and Natural Resources, 30(8), 980-993. https://doi.org/10.1080/08941920.2016.1273417

Scoones, I. (2014). Zimbabwe's Gold Rush: Livelihoods for the Poor or a Patronage Economy or Both?. [Online] Available:

https://zimbabweland.wordpress.com/2014/01/27/zimbabwes-gold-rush-livelihoods-for-the-p oor-or-a-patronage-economy-or-both

Shoko, D., \& Veiga, M. (2003). Information about the GMP Project Site in Zimbabwe. Assistant to Country Focal Point Report to Global Mercury Project, November, 2003, pp. 15.

Suttler, H. (2006). Research and Evaluation for busy practitioners. A Time saving manual. Bristol: The policy press.

Van-Stratten, P. (2002). Rocks for Crops: Agro-minerals of Sub-Saharan Africa. [Online] Available: http://www.lrs.uoguelph.ca/Faculty\%20ect\%20pages/vanstra.html

World Bank. (2009). Mining Together. Large-scale Mining meets Artisanal Mining. CASM (Communities and Small-scale Mining) (CASM). Washington DC. [Online] Available:

https://openknowledge.worldbank.org/

\section{Copyright Disclaimer}

Copyright for this article is retained by the author(s), with first publication rights granted to the journal.

This is an open-access article distributed under the terms and conditions of the Creative Commons Attribution license (http://creativecommons.org/licenses/by/4.0/). 